\title{
How to achieve the climate targets? Spatial planning in the context of the German energy transition
}

\author{
Julia Wiehe ${ }^{*} \mathbb{D}$, Christina von Haaren and Anna Walter
}

\begin{abstract}
Background: The transition of the energy system to renewable energy depends on how successfully the national objectives can be implemented at the lower planning levels. Germany pursues an incentive-oriented policy that is not spatially targeted and lets regional and local stakeholders determine where and how renewable energies are used.

A core question is how to achieve the national goals, in a federal system that allows freedom of planning for the local communities. The aim of this paper is to show the discrepancies between the current expansion of wind energy and the necessary expansion that is derived from a scientific analysis.

Methods: The study examined the policy objectives for the expansion of wind energy, based on a literature analysis. In a second step, the regulatory competences and spatial planning at the various levels and their influence on the expansion were explored. In a third step, the current procedure was compared with scientific scenarios of the energy system in 2050 and concretized using the example of the Hannover Region.

Results: The theoretical and empirical analysis shows that people at regional level underestimate their responsibility for contributing to energy transition. The expansion targets for wind energy in the Hannover Region projected in the scientific scenario are above the minimum demand that the local authorities have assumed. The same applies to the state of Lower Saxony, which underestimates its own wind energy potential and thus its necessary contribution to achieving the national targets.

Conclusions: We propose a nationwide coordinated strategy for the successful implementation of the energy transition. With the methodology described, regional targets can be determined and the responsibility of the region and the local actors can be clarified. With the help of spatial planning and public participation, the energy transition can be achieved with this approach.
\end{abstract}

Keywords: Energy transition, Implementation of climate targets, Regional planning, Wind energy

\section{Background}

Climate protection is one of the central challenges of the twenty-first century-in Germany and worldwide. At the Paris Climate Conference in 2015, international climate protection agreements were established to combat climate change, which were subsequently incorporated into national climate protection plans. At the international level, increased efforts are made to accelerate the radical restructuring of the economy and energy supply and to

\footnotetext{
* Correspondence: wiehe@umwelt.uni-hannover.de Institute of Environmental Planning, Leibniz University Hannover, Herrenhäuser Str. 2, 30419 Hannover, Germany
}

achieve the very ambitious goals. The necessity of taking action and activating all societal actors has become clear. Numerous scenarios show that the longer implementation is delayed, the greater the technical and economic challenges will be. The coming years will be decisive in addressing climate change [1]. For this reason, targets for the use of renewable energies have been formulated in more than 150 countries worldwide. Targets focus on achieving a certain share of the total electricity generation with renewables, a certain mix of renewable energies or the capacity for certain renewable technologies [2]. Long-term targets are important instruments that

(c) The Author(s). 2020 Open Access This article is distributed under the terms of the Creative Commons Attribution 4.0 International License (http://creativecommons.org/licenses/by/4.0/), which permits unrestricted use, distribution, and reproduction in any medium, provided you give appropriate credit to the original author(s) and the source, provide a link to the Creative Commons license, and indicate if changes were made. 
provide investment security and long-term revenues for operators [1].

Germany committed itself in Paris to reducing greenhouse gas emissions by 80 to $95 \%$ by 2050 [3]. In order to achieve this, the government has decided to fundamentally restructure the energy system, as the energy industry accounts for a large share of greenhouse gas emissions (around 40\%) [3]. The resulting necessary expansion of renewable energies by 2050 must use natural resources efficiently and find acceptance in society. In view of the strong competition for land use in both rural and urban areas, this also means that renewable energies must be expanded to the most efficient extent to save space, as "pressure on land" is growing.

In recent years, various studies have focused on the energy yield potential in Germany and the possible development paths. In addition to models in which the focus is on reducing greenhouse gases [4-6], there are analyses to calculate the energy yield potential and nationwide spatial analyses to determine the potential area needed for individual energy sources (e.g. [7-10]).

Despite the very different assumptions and investigation methods in the scenarios, the studies unanimously show that the area available in Germany is sufficient to sustainably achieve the required energy supply from renewable energies. However, these studies on the transition of the energy system over the past 10 years have not been able to effect the necessary expansion of those technologies. Although renewable energies can now meet approximately $38 \%$ of electricity consumption, wind energy shows a significantly lower increase especially in 2018 [11]. The previous spatially unspecific incentives for expansion have caused environmental impacts and met with resistance among local stakeholders. Since suitable technologies are now available and studies show that the potential area is sufficient, the lack of wind energy expansion is assumed to be related to the planning and allocation of wind turbines.

Obviously, the current and past strategies for implementing the expansion targets for renewable energies are not efficient enough. Germany pursues an incentiveoriented policy without spatially specific targets. Furthermore, decisions about where and how renewable energy plants are located are made at the state, regional and local level. At the national level, the overall implementation goals for the lower planning levels have not been specified, possibly to avoid too much top-down regulation that is unnecessary and politically difficult.

The current literature lacks an overview of the objectives at all federal levels. Only if the objectives are clearly defined, the implementation on local level can be started stringently. The existing analyses of particular funding or implementation instruments, therefore, do not go far enough. They offer good tools for assessing the degree to which instrument in question achieve targets, but they always assume that the objectives have been clearly and correctly defined. In contrast to this, the present paper shows an overarching view and reveals the discrepancies in the hierarchy of targets. Only if these are clearly coordinated can the appropriate supporting instruments for energy transition be found. A core question for successful energy governance in Germany is, therefore, how can the national goals be achieved sustainably, in a federal system that allows local communities a strong freedom of planning?

In this context, we will explore economies of scale and the assumption that incentives only, and the understanding of regional authorities, are sufficient to achieve the supra-regional objective of sustainable transformation to renewable energies. We will do this, on the one hand, with the theoretical discussion of governance options and, on the other, through the investigation of a concrete case study. Lower Saxony and the Hannover Region consider themselves to be forerunners of climate protection. They have experience with onshore wind energy for more than two decades, both in production and construction as well as in planning. Therefore, the "Energy state Lower Saxony" [12] should serve as good role model for achieving energy targets.

Finally, we will report on possibilities for further development of governance in the field of renewable energies in Germany.

\section{Which renewable energy governance solutions should be considered in Germany?}

The conflict between goals on high political levels and unsatisfactory implementation on the local level could also be described as a mechanism of spatial, functional or institutional mismatch [13-15].

These mechanisms are known, for example, from nature conservation. They occur when functional areas defined by nature conservation objectives, such as nature conservation areas or river catchment areas, exceed the political boundaries of the institutions responsible for management. Scale problems also arise when an area or landscape element is considered valuable on a higher political level (as in the case of the priority species of the European Habitat Directive), but control is left to a lower level. Furthermore, local interventions can become significant at the higher level if they occur in large numbers and the cumulative effects, e.g. the hedgerow removal, lead to regional or Germany-wide risks of biocoenosis [16].

The character of many environmental resources as collective goods leads to the fact that local activities often benefit from the exploitation of natural resources but do not bear the costs. On the other hand, those local actors have to bear the costs of preserving valuable 
ecosystems without directly experiencing the benefits (e.g. for future generations) [17]. To resolve these scale effects, different approaches are discussed in the literature.

On the one hand, arguments are put forward to the effect that responsibility for environmental matters should be placed at national or even supra-national level. Actors at higher spatial levels have greater technical problemsolving competence and often better resources for implementation [18].

On the other hand, arguments found in the literature (see a more detailed discussion concerning renewable energies in [16]) put the local level in the foreground of implementation strategies and support the bottom-up strategy. In many cases, objectives at higher levels are defined in relatively general terms and must be made more concrete on site, often with great scope for local actors to determine the details. For example, different local conditions have led to decisions that are positive for the environment. In such cases, these decisions include the local knowledge, local participation, the selforganization of local interest groups, mutual trust between actors and social control, e.g. with regard to compliance with agreed rules $[19,20]$.

The problem of the spatial fit of responsibilities is also evident in the field of energy transition. The fundamental problem, climate change, can clearly be seen at the international level. However, it is still unclear how responsibility for the environmentally friendly development of renewable energies can be broken down from the federal level to the locally responsible without failing to meet the targets.

The local/regional political level makes decisions about renewable energy allocation. However, the majority of citizens do not benefit directly from the installation of wind power plants or big energy crop cultivations in their region-even if this is done in the name of fighting global climate change. The policy objective remains abstract, and stakeholders do not understand what their responsibly is in terms of local contribution to halt climate change. The motto: "Think global act local" is not operationalized.

In such cases, the implementation of the more general overarching objectives can only be ensured if the higher authorities do not delegate their competencies. This means that control mechanisms that measure compliance need to be introduced, and if necessary, sanction deviations would need to be put in place at the next higher level. The draft Lower Saxony Climate Protection Act, for example, proposes requirements for the expansion of wind energy in municipalities. However, the government coalition has not reached an agreement on concrete specifications [21]. Parts of the state government consider the federal level to be responsible for climate protection and therefore want to wait for the national climate protection law before developing their own legislation.

The distribution of tasks in environmental management is crucial in order to develop suitable structures for implementation and to achieve the targets. The 12 normative principles for the distribution of tasks in environmental management proposed by Mostert [22] serve as a yardstick for assessing whether a task is at the right scale level. These principles are helpful in the practical application of energy governance. Mostert [22] states that the distribution of responsibilities should respect the following principles:

(1) Capacity: responsibility for specific tasks is given to actors that possess or can develop the resources needed to perform these tasks well.

(2) Lowest social costs: minimize total costs for society.

(3) Causation: polluter pays principle.

(4) Interest: those with an interest in a management task should be (financially) responsible.

(5) Scale: the management scale should match as much as possible the scale of the management issues.

(6) Subsidiarity: tasks should be performed at the lowest possible level.

(7) Structural integration: responsibilities for closely related tasks should be combined in one hand.

(8) Separation: tasks should be allocated to different actors.

(9) Solidarity: the risks and burdens to which individual members are exposed should be borne by the group as a whole.

(10)Transparency: the allocation of responsibilities should be clear.

(11)Stability: the allocation of responsibilities should not change too often, but it should be adapted to changing circumstances.

(12)Acquired rights: acquired rights should be respected and if necessary compensation should be offered.

The increased demands for coping with national and international challenges, such as climate change, should be reconciled with the traditional rights and interests of local politics in co-determination (see principle 12 acquired rights) and the local population in participation [22]. In particular, Mostert [22] emphasizes the capacity principle (1) because a level that lacks the resources to take on a task cannot be entrusted with it or the capacity should be increased. At the same time, collective and individual responsibility at the local level is limited by the available capacity. With respect to the problem considered here, this means that better governance of renewable 
energy should take place in a clear framework of national targets, but should leave as much discretion as possible allowed by the capacities at the lower level.

Also, the principles illustrate how good governance can help implement the energy transition. For example, the polluter pays principle (3) points out that we are all co-causers of climate change and should carry the burden accordingly. There is sufficient interest (4) to press ahead with the energy transition. This can be seen in the elaboration of the state and regional plans, in which "substantial space" is already given to wind energy by appropriate land designations. The interest at the local level remains unclear, but it could be motivated by the federal level through incentives for a sustainable energy transition. In order to achieve the national targets, the lower levels can be given sufficient leeway for adapted solutions reflected in principle 5 of the appropriate scale. In accordance with the principles of subsidiarity and separation (6 and 8), the achievement of objectives could be shifted as much as possible to the lower level without jeopardizing the overall objective. In order not to put too much strain on solidarity (9) among the municipalities and regions subject to different burdens, incentives for energy transition and balancing mechanisms must be provided at the national level. If the path towards this is transparent (10) with stable responsibilities (11), the energy transition could be implemented in the existing structures, but new structures are necessary for the objectives and control at the federal level.

These principles may contradict each other in practice, but they form a good framework for decisionmaking in order to evaluate whether a task is on the right scale. The correct allocation of responsibilities to different decision-making levels will help to achieve better governance results and thus the national climate targets.

In the following, we will examine whether such a strategy would lead to a different energy policy in the Hannover region. Using the example of Lower Saxony and the Hannover Region, we will first examine the current energy targets and their implementation within the framework of German climate policy. These political goals will be compared with scientific studies on energy scenarios and the resulting new need for action at the various political levels.

\section{Methods}

The analysis of the current objectives and responsibilities of the three levels of investigation, i.e. federal, state and region, is based on a literature analysis. The study examined the policy objectives for the expansion of renewable energies with a focus on wind energy use. In a second step, the regulatory competences and spatial planning at the various levels and their influence on the expansion of wind energy were explored. In a third step, the political targets for energy expansion were compared with a scientific approach to implementing the energy transition. The projected future energy demand requires an even greater expansion of wind energy, which can be spatially delineated with geo-information systems. The study uses the federal state of Lower Saxony and the Hanover region as a concrete example, in which current plans with statements on wind energy expansion are available and many years of experience with the use of wind energy already exist $[23,24]$.

The third step is based on the study "Naturally compatible energy supply from 100\% renewable energies 2050" [7], in the following referred to as EE100. The central means of presentation in EE100 are three scenarios which are intended to provide a perspective on a possible human- and nature-compatible energy supply from renewable energies in the year 2050.

A spatial approach was chosen in EE100 to determine the potential areas for human- and nature-compatible electricity production, since available land is a crucial limiting factor for the expansion of renewable energies. In the scenarios, the areas were selected on which no relevant risks for humans and nature are expected from wind power and photovoltaic use. These are, for example, areas that are already unusable today, such as settlements, infrastructure, nature reserves and national parks. In addition, there are the future nature conservation zones to be developed by 2050, which are to be expected from the land requirements of the implementation of the national biodiversity strategy [7].

The processing of spatial data in the geographic information system (GIS) makes it possible to focus from the national scale to lower levels and thereby to draw conclusions about the usable area of a federal state or a region. The correlation of the scientifically determined potential area with the actual plans created by the planning institutions for the purpose of implementation highlights the many challenges of the transition of energy systems. In addition to the spatial analysis of the usable areas, the objectives and the associated decision-making responsibilities at the different levels of the German planning system are therefore examined in this paper.

\section{Results}

Current energy policy and implementation

At the federal level, the Federal Government has set several targets in a commitment to a strong expansion of renewable energies. As part of the "Renewable Energies Directive 2009/28/EC", Germany intends to make $18 \%$ of gross final energy consumption from renewable sources available by 2020 [25]. 
Current figures show that 14\% was achieved in 2018 and further expansion is necessary, even though the share of renewables in the electricity sector is already $38 \%$ [25].

The targets for the expansion of renewable energies and the specific technologies from the Federal Government's climate protection plan are laid down for the federal level in the "German Renewable Energy Sources Act" (EEG [26]). By 2050, 80\% of gross electricity consumption is to come from renewable energies. An annual gross addition of onshore wind turbines with an installed capacity of $2.8 \mathrm{GW}$ in the years 2017 to 2019 and $2.9 \mathrm{GW}$ from 2020 is stipulated for the yield from wind energy. In this way, $87 \mathrm{GW}$ installed capacity would be added by 2050 . However, the electricity requirement for the year 2050 is not included or forecasted in the legal text, so that it remains unknown whether the proposed expansion will actually achieve the climate targets.

The law only provides for spatial allocation via the "reference yield model" and the definition of a grid expansion area. In principle, the funding of windgenerated electricity is linked to the yield of the plant, so the wind speed of the site is the main criterion for an operator's choice [27]. In order to enable the use of sites with lower outputs, so-called correction factors are specified in $\$ 36 \mathrm{~h}$ EEG with the aim of subsidizing higher or lower yields that deviate from a fixed reference plant. This "reference yield model" is intended to differentiate the funding rate at the relevant site and provide incentives for nationwide expansion [27]. However, concrete requirements or expansion targets for the federal states are not specified.

\$36 EEG 2017 and the supplementary ordinance implement a "grid expansion area" as a reaction to regional grid congestion. In those areas, the increase in installed capacity is limited to " 58 percent of the annual average installed capacity commissioned in this area between 2013 and 2015” (EEG 2017 \$36c). This article will apply until the necessary grid expansion has been completed. The federal grid agency has determined that the northern part of Lower Saxony, Bremen, Schleswig-Holstein, Hamburg and Mecklenburg-Western Pomerania belong to this zone (EEAV $2017 \$ 10$ [28]). This regulation will have a very strong influence on the expansion of wind energy [27], since it is limited above all in the particularly windy regions. However, it should be seen more as a transitional solution for better integration of grid expansion and increase the share of the renewables than as an instrument of spatial planning.

At the national level, statements on the spatial distribution of the objectives of supra-regional interests could be made by spatial planning, which in Germany is divided into four levels. At the federal level, the objectives and policies of sustainable spatial planning are defined. These are to be concretized at the lower levels, but remain in the law without spatial reference. In the field of energy supply, the ROG stipulates that a "cost-effective, safe and environmentally friendly energy supply" (ROG [29]) must be achieved. It is necessary to take into account the spatial requirements of climate protection, both through measures that prevent climate change and through adaptation measures (ROG $\$ 2$ para. 2). The aim is to create "spatial conditions for the expansion of renewable energies, for the economical use of energy and for the preservation and development of natural sinks for climate-damaging substances and for the storage of these substances" (ROG $\$ 2$ para. 2). These principles are only vaguely defined in terms of content, and there is no federal legal hierarchy between the conflicting interests in many aspects [30].

To concretize these principles, the Standing Conference of Ministers responsible for Spatial Planning adopted "Concepts and Strategies for Spatial Development in Germany", which in addition to the legal requirements also refers to the objectives of the climate protection plan [31]. All necessary actions to increase the share of renewable energies are delegated to the lower planning levels. A cartographic illustration shows the current spatial distribution of renewable energy sources at the time of publication in 2016 [31], but does not contain any forwardlooking planning and distribution ideas. The hierarchical planning system in Germany does not provide for topdown planning of energy plants at national level. In the conventional energy system with supply via large power plants at a few locations in the country, comprehensive planning of energy generation was not necessary.

The spatial determination of the planning occurs at the federal states level and below. In the spatial planning programmes of the federal states, energy yield targets are formulated in the context of energy supply, or minimum area shares for renewable energy generation are defined [32]. These requirements are supplemented by state-specific decrees. In Germany, there are currently 14 wind energy decrees with different expansion targets and specifications such as distance regulations or wind energy use in forests [33].

The Lower Saxony Wind Energy Decree is also intended to support the expansion of wind energy use and provide guidance for regional planning authorities. The decree regulates the technical supervisory responsibilities of the state, such as immission control, construction and nature conservation issues. The decree and corresponding guidelines are intended to support an environmentally and socially compatible expansion of wind energy use in Lower Saxony [34].

In addition, the state government prepares regular reports on the energy transition in which the goals and 
implementation strategies for Lower Saxony are described. According to the report for 2018, the current installed capacity of wind energy is $11 \mathrm{GW}$ and is expected to rise to $20 \mathrm{GW}$ by 2050 [12]. This will be achieved by installing new wind turbines but also by repowering 1500 wind turbines state-wide. These have been in place for 15 to 20 years and must be renewed. The higher output of the new technologies should significantly increase the energy yield without having to exploit new sites [12].

The spatial planning programme of Lower Saxony refers to the expansion of renewable energies and to the fact that the regional plans are to be designed accordingly. The wind energy priority areas are to be secured in binding regional plans. Specific expansion targets will be set for 10 districts with particularly high wind speeds. For a total of $1.4 \mathrm{GW}$ of installed capacity, targets are set in the regional planning programme according to the yield potential of the regions [34].

In the Wind Energy Decree, supplementary area potentials were calculated for all districts of Lower Saxony. Even if these are not binding specifications for regional or urban land use planning, this calculation clearly shows the contribution that the individual administrative districts must make in order to achieve the nationwide expansion target of $20 \mathrm{GW}$ in the long term [34].

For the Hannover region, it was determined from the state-wide analysis that $1.9 \%$ of the total area is suitable for the production of wind power, which corresponds to around 59,500 ha. Of this total area, Hannover would have to use approximately 4400 ha to contribute its share to the expansion target of $20 \mathrm{GW}$ throughout Lower Saxony [34]. At the state level, therefore, important preconditions have already been laid for a large-scale expansion of wind energy adapted to local conditions.

At the regional level, suitable areas for wind energy use can be further concretized in "priority areas". In 2014, a total of $1620 \mathrm{~km}$ [2] were secured nationwide in this way, which corresponds to about $0.45 \%$ of the area of the Federal Republic of Germany [35]. Whether the yield potential of these areas is sufficient to achieve the development goals of renewable energies remains unclear. The actual yield depends as much on the wind energy technologies chosen as on the degree of area utilization in practice.

With the Master Plan 2016 [36] and the Regional Planning Programme 2016 [24], the administration of the Hannover Region has defined its own goals and standards for development. The report "Climate-neutral Hannover Region 2050" aims to decrease greenhouse gas emissions by $95 \%$ while reducing energy demand to $50 \%$ compared with 1990 levels. Three hundred forty-two megawatts of wind energy is currently installed. By 2050, this figure is to be increased to $1.15 \mathrm{GW}$ using repowering and more efficient technologies [37].
In the Regional Planning Programme, 31 priority areas with a total area of 3600 ha were designated for this purpose, which corresponds to around $1.6 \%$ of the regions area [24]. With this amount, two thirds of the electricity demand forecasted for the Hannover Region in 2050 could be generated. At present, however, the planning possibilities at the regional level are very limited. Due to incorrect planning, the wind energy section of the Regional Planning Programme was annulled by the Lüneburg Higher Regional Court (5 March 2019). The planning responsibility, therefore, falls to the 21 cities and municipalities, and the expansion of wind energy will thus be carried out on a smaller scale. Each municipality must elaborate land use plans and must give wind energy "substantial" space in their area, in accordance with the BauGB (German Federal Building Code). The term "substantial" is not further defined, and no reference is made to the nationwide expansion targets. This can be seen, for example, in the preliminary draft of the partial land use plan for the city of Barsinghausen [38], which provides for 4 different variants of the priority areas for wind energy: with a size of 46 ha in variant $C$ to 139 ha in variant $A$. The expected energy yield on these areas and the city's contribution to energy transition are not mentioned as development objectives in these calculations. Only the area share is given as a relevant parameter.

The example presented shows that there are only very rough national development goals and that there is no concrete relationship between the goals of the federal and state levels or those of the region. It remains unclear whether the plans and programmes at the lower levels will achieve the expansion and climate protection objectives at the federal level in their totality.

\section{The scientific approach-comparison of results with energy scenarios EE100}

The comparison of the policy objectives with the scientifically determined expansion potentials with regard to the expected energy demand also illustrates the current less target-oriented approach.

In the nationwide potential study EE100 [7], significantly higher expansion targets were formulated for all levels in order to achieve a complete energy supply with renewable energies. The first step was to determine the future energy demand of the Federal Republic of Germany. For the year 2050, it was assumed that all sectors (heat, electricity, transport) are electrified as far as possible, i.e. that the overall electricity demand will increase. The projection was also based on extrapolated population and economic development, an electrification rate in the transport sector, a building renovation rate and efficiency measures in all areas. This very ambitious final energy demand development requires $1362 \mathrm{TWh} / \mathrm{a}$ 
of energy, composed of 818 TWh/a electricity, $229 \mathrm{TWh} / \mathrm{a}$ ambient heat in electric heat pumps and approx. $315 \mathrm{TWh} / \mathrm{a}$ non-electric energy (raw materials for non-electrifiable processes). In order to compensate for fluctuations in the diurnal variation and the course of the year, it was assumed that roughly $50 \%$ of the electricity from renewable sources had to be stored. Due to the associated conversion and storage losses (approx. $50 \%), 1227 \mathrm{TWh} / \mathrm{a}$ of electricity would have to be available (converted to the German government's development target of $80 \%$ renewable energies by 2050 , this would be $982 \mathrm{TWh} / \mathrm{a}$ ).

GIS analyses were used to identify those areas in Germany that are suitable for use by wind power and photovoltaics on rooftops (low value of the protected resources and low sensitivity to construction-, operationand plant-related effects of the energy generation plants). The potential electricity yield of these areas was then calculated. Further renewable energies such as geothermal energy, hydropower or selected biomass potentials were also included in the energy mix.

A total of three scenarios with different technology variation were calculated in the EE100 project. Scenario I "Current technologies and standards for the protection of people and nature" was calculated as a basis for comparison with currently existing power generation technologies. In contrast, in scenario II "Technological trends and expected future technologies in 2050", the efficiency level of the PV systems as well as the output and hub height of the wind turbines was increased. The scenario III "Technical innovation "plus" for human and nature" is an extension of the first and second scenarios to include the yield potential of an innovative wind energy system. In this way, it becomes clear which electricity potentials would arise if the available space was used by a location-adapted combination of different technologies (see Table 1).

In this article, scenario II is used as a comparison scenario because it refers to realistic technological developments up to 2050. The wind turbine used in 2050 has a rated output of $7.58 \mathrm{MW}$ with a hub height of $200 \mathrm{~m}$ and a rotor diameter of $127 \mathrm{~m}$. This plant was simulated on all suitable areas, even if in real life it would not be used at all locations due to economic decisions and would not achieve the optimum number of full load hours everywhere. In planning practice, the wind turbine is always selected on a site-specific basis, but this could not be taken into account in the EE100 project due to the nationwide consideration.

The potential renewable electricity yield in scenario II (TA Lärm) is about $1629 \mathrm{TWh} / \mathrm{a}$, of which $483 \mathrm{TWh} / \mathrm{a}$ are generated from wind energy on land. The shares of the other energy sources are $553 \mathrm{TWh} / \mathrm{a}$ from photovoltaic on rooftops, $113 \mathrm{TWh} / \mathrm{a}$ from offshore wind energy, $50 \mathrm{TWh} / \mathrm{a}$ from geothermal energy and $24 \mathrm{TWh} / \mathrm{a}$ from hydropower. All potential yields would have to be exploited to cover the projected energy demand (electricity, heat and non-electric energy) in 2050 (see Fig. 1).

According to Walter et al. [7], this requires around $240 \mathrm{GW}$ installed capacity using the very powerful wind energy power plants $(7.5 \mathrm{MW})$. If these scientific results are reduced to the government's $80 \%$ target, the demand will be $192 \mathrm{GW}$. This is significantly more than stipulated in the plans and programmes of the Federal Government (see Table 2).

In EE100, the yield potentials were determined independently of administrative boundaries according to the wind conditions of the sites and the sensitivity of human and nature. This results in a heterogeneous distribution within the federal territory and different contributions to the expansion of renewable energies for the federal states. According to Walter et al. [7], an installed capacity of $81 \mathrm{GW}$ would be necessary in Lower Saxony due to the high wind speed in the coastal areas in order to achieve the scenario goal of a $100 \%$ supply nationwide. This corresponds to approx. 11,000 of the powerful wind turbines in this federal state.

Even if the less ambitious expansion targets of the federal government were accepted, 65 GW of installed capacity would have to be achieved in Lower Saxony. Here, too, there is a clear discrepancy between the modelling and the political target of $20 \mathrm{GW}$ of installed capacity.

For the Hannover Region, EE100 calculated that $4.5 \mathrm{GW}$ (respectively $3.6 \mathrm{GW}$ ) of installed capacity can and should be used for electricity from humanand nature-compatible wind energy. This corresponds to around 600 power plants and is thus well above the climate protection targets of the Hannover

Table 1 Characteristics of onshore wind turbines in the scenarios of the study "Naturally compatible energy supply from 100\% renewable energies 2050" (Walter et al. 2018)

\begin{tabular}{|c|c|c|c|c|c|}
\hline \multirow{2}{*}{$\begin{array}{l}\text { Technology } \\
\text { Rated power }\end{array}$} & \multirow{2}{*}{$\begin{array}{l}\text { Scenario I: "status quo" current technologies } \\
\text { and standards for the protection of } \\
\text { people and nature } \\
\text { 3.0 MW }\end{array}$} & \multirow{2}{*}{$\begin{array}{l}\text { Scenario II: technological trends } \\
\text { and expected future technologies } \\
\text { in } 2050 \\
7.58 \mathrm{MW}\end{array}$} & \multicolumn{3}{|c|}{$\begin{array}{l}\text { Scenario III: technical innovation } \\
\text { plus for man and nature }\end{array}$} \\
\hline & & & $13 \mathrm{~kW}$ & $3.0 \mathrm{MW}$ & $7.58 \mathrm{MW}$ \\
\hline Hub height & $122 \mathrm{~m}$ & $200 \mathrm{~m}$ & $13.5 \mathrm{~m}$ & $122 \mathrm{~m}$ & $200 \mathrm{~m}$ \\
\hline Rotor diameter & $115.7 \mathrm{~m}$ & $127 \mathrm{~m}$ & - & $115.7 \mathrm{~m}$ & $127 \mathrm{~m}$ \\
\hline Sound power level & $105.0 \mathrm{~dB}[\mathrm{~A}]$ & $108.5 \mathrm{~dB}[\mathrm{~A}]$ & - & $105.0 \mathrm{~dB}[\mathrm{~A}]$ & $108.5 \mathrm{~dB}[\mathrm{~A}]$ \\
\hline
\end{tabular}




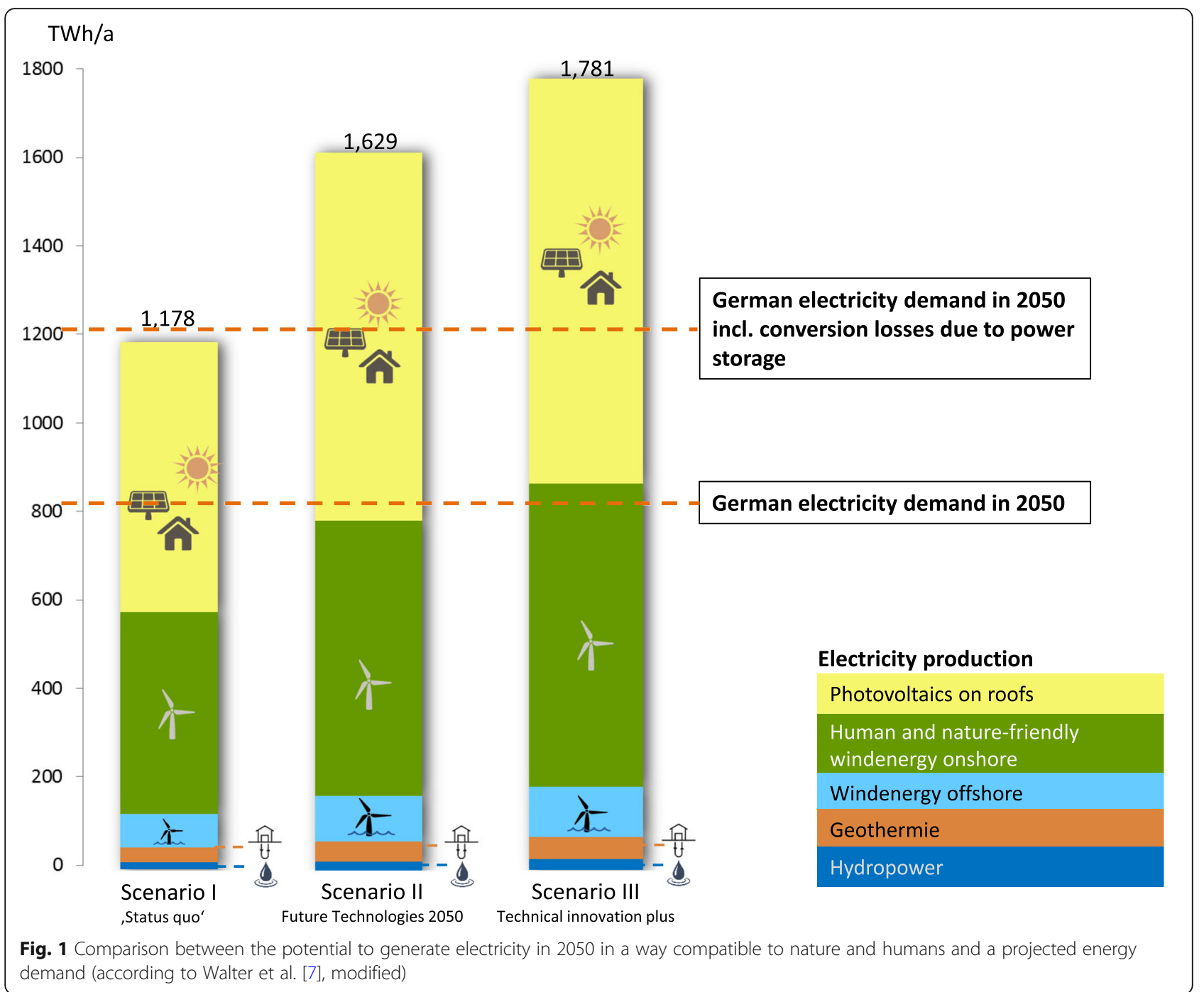

Region, which wants to achieve around $1.15 \mathrm{GW}$ of installed capacity.

\section{Discussion}

The calculation of the scientific approach is subject to some uncertainties when determining the future energy demand or the potential energy production areas. The present study is based on the energy demand calculations from the EE100 project, which assumed very ambitious savings targets for all consumption sectors. A comparison of these assumptions with other potential studies shows that they are selected and weighted very differently [4-6]. What they all have in common is that they assume a reduction in energy demand to around

Table 2 Policy targets, status of implementation and necessary expansion of onshore-wind energy by 2050 on different planning levels in Germany

\begin{tabular}{llll}
\hline Level & $\begin{array}{l}\text { Policy target for the expansion } \\
\text { of wind energy by 2050 (installed cap.) }\end{array}$ & $\begin{array}{l}\text { Status of implementation in } \\
2018 \text { (installed cap.) }\end{array}$ & $\begin{array}{l}\text { Necessary expansion according } \\
\text { to EE100 (installed cap.) }\end{array}$ \\
\hline Nation & $137 \mathrm{GW}^{1}$ & $50 \mathrm{GW}^{2}$ & $240 \mathrm{GW}^{5}$ \\
Lower Saxony (federal state) & $20 \mathrm{GW}^{3}$ & $11 \mathrm{GW}^{3}$ & $81 \mathrm{GW}^{5}$ \\
Hannover Region (region) & $1.15 \mathrm{GW}^{4}$ & $342 \mathrm{MW}^{4}$ & $4.5 \mathrm{GW}^{5}$ \\
\hline
\end{tabular}

${ }^{1}$ German Renewable Energy Sources Act 2017 (EEG)

${ }^{2}$ BMWi Bundesministerium für Wirtschaft und Energie $(\mathrm{Hg})[25]$

${ }^{3}$ Niedersächsisches Ministerium für Umwelt, Energie, Bauen und Klimaschutz (ed) [12]

${ }^{4}$ Klimaschutzagentur Region Hannover (ed) [37]

${ }^{5}$ Walter et al. [7] 
half of today's consumption. This would require intensive energy efficiency measures to be implemented. It can therefore be expected that the real demand in 2050 will be higher than assumed here. The development of demand-oriented expansion targets therefore remains a challenge as they depend on the achievement of the energy efficiency targets.

The calculation of usable land potential is also not clear in all land categories. It depends strongly on the quality of the underlying geodata. These are not always available nationwide or are collected in varying degrees of detail by the federal states. An uncertainty analysis of the GIS model is currently being prepared in order to improve the results of the analyses.

However, the scientific scenarios and GIS analyses show that the potentials for renewable energies can be represented spatially and overlaid with the nature conservation restrictions concerning the allocation of the plants. This opens up possibilities not only for a selection of plant types and their distribution in space that is compatible with human well-being and nature, but also for the calculation of the energy potential for any given area. This also makes it possible to calculate at the federal level how much energy can be produced in an environmentally friendly manner in 2050 and whether this is sufficient, for example, to fulfil the Paris Agreement and which conflicts of objectives between nature conservation and climate protection may remain.

If the expansion of renewable energies is downscaled to regions and municipalities, their respective contribution will be very different, since the human- and naturecompatible production potential of the individual energy sources is distributed spatially differently. A site-specific expansion cannot be achieved with the currently existing economic incentive mechanisms and legal requirements that are not related to space. Although spatial planning at the regional level can take a spatially differentiated approach, it cannot ensure that the amount of energy required for the federal objective is generated. The federal level would therefore have to take action here.

The tasks to be undertaken at the respective levels are therefore not clearly defined. Even if it is assumed that the responsible federal level can hardly handle the entire implementation and that a large part of the responsibility for implementation or consideration is left to the lower levels, at the same time, there are no mechanisms available which can ensure that the targets with regard to the energy transition are achieved [16].

In principle, there would have been many advantages, also in the sense of the 12 principles mentioned above according to Mostert [22], if the lower levels had also been assigned responsibility for planning and implementation. For this to happen, however, there would have to be sufficient interest on the local level (principle 4) in the complete implementation of the energy transition and the capacities (principle 1) would have to be available. This does not seem to be the case at present, even though support for renewable energy is generally high among the general population. The acceptance of wind energy in particular has fallen significantly [11], and so, judicial reviews of regional plans and designated priority areas are becoming increasingly frequent, whether by subordinate municipalities or other actors. In 2015, for example, regional plans were declared temporarily inadmissible in the entire federal state of Schleswig-Holstein until the Higher Administrative Court carried out a detailed examination [39]. In the Hannover region, too, the legal disputes and protracted approval procedures block the development and the project planners of the wind turbines are under economic pressure [40]. The expansion of wind energy use is therefore currently not possible, and the region will not be able to achieve its climate targets for 2020 [41]. If planning is not carried out using the instrument of regional planning priority areas, wind energy plants can only be planned by individual municipalities within the framework of communal urban land use planning. The necessary large-scale expansion is thus clearly inhibited and is neither cost- nor area-efficient. Also, the systematic expansion on areas with high wind speed and at the same time low risk of impairment of nature and landscape is no longer necessarily given, and the human and nature compatibility of the wind energy use is not guaranteed at all sites.

An increase in land usage is to be expected if the plants are constructed on less suitable sites. Due to conditions imposed by the licencing authorities, they often have to be shut down in certain phases. This is done, for example, during the phase of breeding of endangered bird and bat species. Limited operation is also possible in special weather conditions, e.g. when strong winds from certain directions increase noise pollution and the adjacent settlement is impaired. In addition, possible times of cast shadows during the operation of the plant must be taken into account, which also lead to the shutdown of the plant. Each form of shutdown causes lower electricity yields of the individual plants, so that more of them have to be installed in total.

\section{Conclusions}

The study shows that governance in the field of renewable energies in Germany has not yet been adequately structured. The assumption formulated at the beginning is therefore not correct, that only incentives and the understanding of the regional authorities are sufficient to achieve the supra-regional goal of a sustainable transition to renewable energies. The example of wind power generation makes it very clear that mandatory and interdependent targets must first be defined for the various 


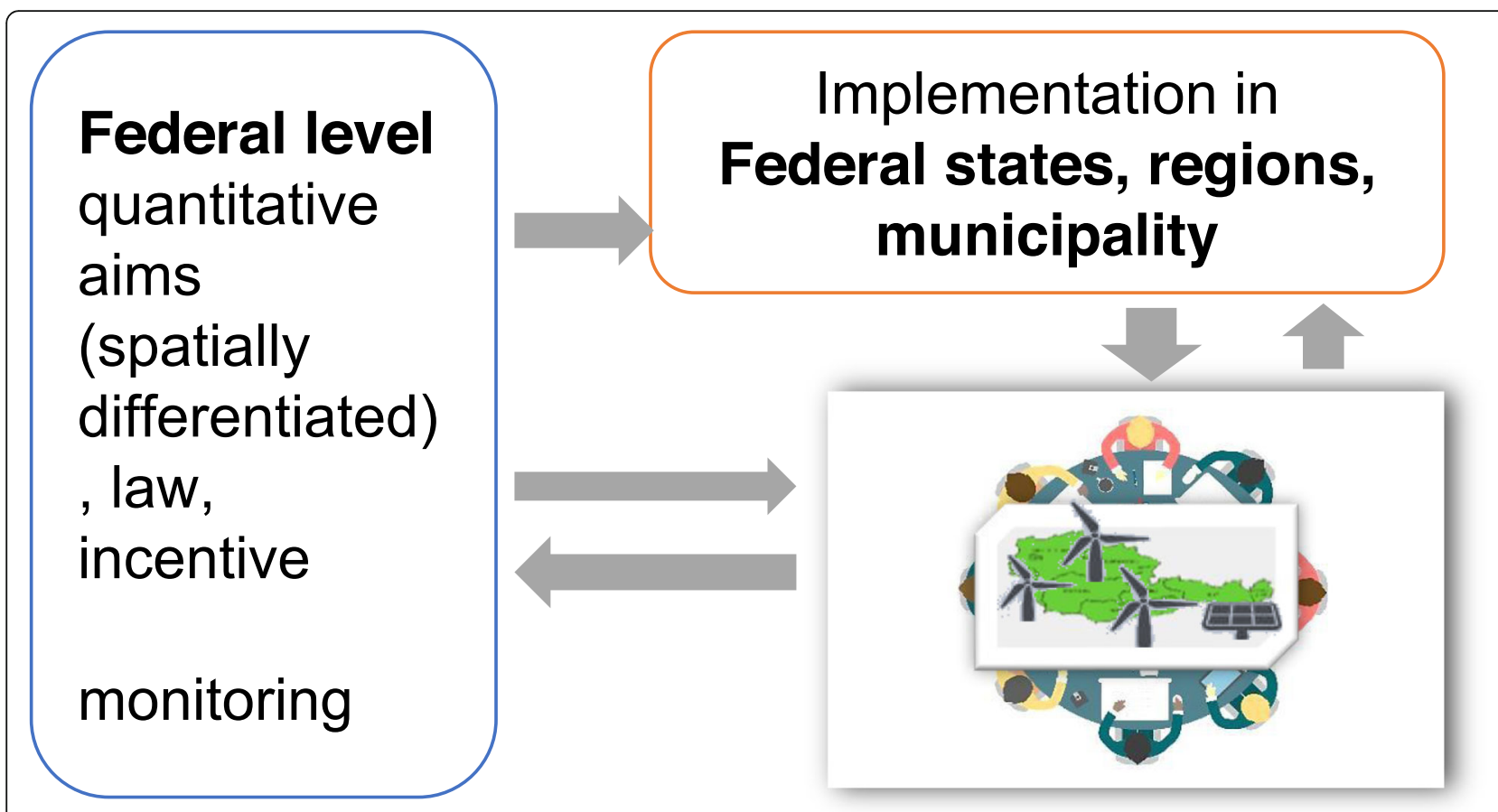

Fig. 2 Better achievement of targets can be accomplished through the interaction of political decision-making levels in implementation (according to Walter et al. [7], modified)

decision-making levels. If these are clearly structured, governance can be designed in accordance with Mostert's principles [22].

A nationwide coordinated strategy with clearer development goals is necessary to ensure that regions and municipalities become aware of their responsibility within the framework of the entire goal. At the same time, however, they must not relinquish their decision-making sovereignty in spatial planning or land use issues [7].

With the help of the GIS analysis shown, the potential areas at different spatial levels can be determined, on the basis of which expansion targets for renewable energies can be defined. The first step is to break down the national energy targets to the lower political decisionmaking levels, with a stronger binding effect than currently. This framework must be communicated clearly and transparently and must be given interdepartmental binding force in its implementation at the lower decisionmaking levels. This could be achieved by establishing a national sectoral planning for energy generation, analogous to the network development planning $[7,30]$.

The unplanned allocation of wind turbines could be counteracted through a planning obligation on the part of the municipalities and the use of areas that are suitable from a nature and spatial planning point of view could be achieved. At the same time, the construction of individual plants in less suitable areas can be prevented in this way.
Clear development targets at the lower levels and a control mechanism at the federal level make it possible to monitor the success of the energy transition and make it clear whether the targets have been achieved or where adjustments need to be made: What happens if everyone acts like us? What contribution does our region have to make and how can we exchange ideas with others (see Fig. 2)? [7].

At the federal level, it would be possible to continuously identify the need for additional control by comparing the (interim) results achieved with the framework conditions set and the (interim) objectives of the energy transition [7]. It is hoped that the German "Energiewende" will be a success story if it becomes clear what role both society and each individual has in fulfilling this goal.

\section{Abbreviations}

EE100: The study "Naturally compatible energy supply from 100\% renewable energies 2050"; EEG: German Renewable Energy Sources Act; GIS: Geographic Information System; Habitat Directive: Council Directive on the conservation of natural habitats and of wild fauna and flora; ROG: German Regional Planning Act

\section{Acknowledgements}

The authors thank K. Ammermann and C. Strauß from the Department II 4.3 "Nature Conservation and Renewable Energies" for their kind contribution to our research work. We thank B. Bredemeier and J. Thiele for helpful comments on the manuscript and B. Warren-Kretzschmar for the linguistic 
corrections. The publication of this article was funded by the Open Access Fund of the Leibniz University Hannover.

\section{Authors' contributions}

JW designed the present study, analysed the literature and wrote the manuscript. $\mathrm{CVH}$ supervised the research and wrote parts of the manuscript. AW calculated the regionalised area and yield potentials. The author(s) read and approved the final manuscript.

\section{Funding}

The cited project "Naturverträgliche Energieversorgung aus 100\% erneuerbaren Energien 2050 (EE100)" was funded by the Federal Agency for Nature Conservation with funds from the Federal Ministry for the Environment, Nature Conservation and Nuclear Safety (BMU) (FKZ no. 351582 4300).

\section{Availability of data and materials}

The data that support the findings of this study are available from www. umwelt.uni-hannover.de/ee100 but restrictions apply to the availability of these data, which were used under licence for the current study, and so are not publicly available.

\section{Ethics approval and consent to participate}

Not applicable.

\section{Consent for publication}

Not applicable.

\section{Competing interests}

The authors declare that they have no competing interests.

Received: 22 February 2019 Accepted: 5 February 2020

Published online: 19 February 2020

\section{References}

1. Teske S, Pregger T, Pagenkopf J, van den Adel B, Deniz Ö, Meinshausen M, Giurco D (2019) Chapter 13: discussion, conclusions and recommendations. In: Teske S (ed) Achieving the Paris climate agreement goals. https://doi. org/10.1007/978-3-030-05843-2_13.

2. REN21 - Renewable Energy Policy Network (2019) Renewables 2018 Global Status Report. http://www.ren21.net/gsr-2018/chapters/chapter_02/ chapter_02/. Accessed 23 July 2019.

3. Bundesministerium für Umwelt, Naturschutz, Bau und Reaktorsicherheit (BMUB) (ed.) (2016) Klimaschutzplan 2050. Klimaschutzpolitische Grundsätze und Ziele der Bundesregierung. Berlin. $92 \mathrm{~S}$

4. Öko-Institut, Fraunhofer ISI (ed.) (2015) Klimaschutzszenario 2050. 2 Endbericht. Studie im Auftrag des Bundesministeriums für Umwelt, Naturschutz, Bau und Reaktorsicherheit

5. Deutsches Zentrum für Luft- und Raumfahrt (DLR), Fraunhofer Institut für Windenergie und Energiesystemtechnik (IWES), Kassel Ingenieurbüro für neue Energien (IFNE) (eds.) (2012) Langfristszenarien und Strategien für den Ausbau der erneuerbaren Energien in Deutschland bei Berücksichtigung der Entwicklung in Europa und global. Schlussbericht. BMU - FKZ 03MAP146

6. PROGNOS (2014) Endbericht. Entwicklung der EnergiemärkteEnergiereferenzprognose. Projekt Nr. 57/12. Studie im Auftrag des Bundesministeriums für Wirtschaft und Technologie

7. Walter A, Wiehe J, Schlömer G, Hashemifarzad A, Wenzel T, Albert I, Hofmann L, zum Hingst J, von Haaren C (2018) Naturverträgliche Energieversorgung aus 100\% erneuerbaren Energien 2050. BfN-Skripten 501 160 S. Bonn - Bad Godesberg. https://www.bfn.de/fileadmin/BfN/service/ Dokumente/skripten/Skript501.pdf. Accessed 23 July 2019

8. Lütkehus I, Salecker H, Adlunger, K. (2013): Potenzial der Windenergie an Land. Studie zur Ermittlung des bundesweiten Flächen- und Leistungspotenzials der Windenergienutzung an Land. Umweltbundesamt (ed.). $51 \mathrm{~S}$

9. IWES Fraunhofer Institut für Windenergie und Energiesystemtechnik $(\mathrm{Hg})$ (2011) Studie zum Potenzial der Windenergienutzung an Land Kurzfassung. $29 \mathrm{~S}$

10. WWF Deutschland (Hg.) (2018) Zukunft Stromsystem II - Regionalisierung der erneuerbaren Stromerzeugung - Vom Ziel her denken. $162 \mathrm{~S}$

11. Agora Energiewende (2019) Die Energiewende im Stromsektor: Stand der Dinge 2018. Rückblick auf die wesentlichen Entwicklungen sowie Ausblick auf 2019. 74 S
12. Niedersächsisches Ministerium für Umwelt, Energie, Bauen und Klimaschutz (ed) (2018) Energiewendebericht 2018. 52 S

13. Bergsten A, Galafassi D, Bodin Ö (2014) The problem of spatial fit in socialecological systems: detecting mismatches between ecological connectivity and land management in an urban region. Ecol Soc 19(4):6

14. Folke C, Pritchard L, Berkes F, Colding J, Svedin U, Pritchard L (1998) The problem of fit between ecosystems and institutions (IHDP Working Paper No. 2.)

15. Moss T, Newig J (2010) Multilevel water governance and problems of scale. Setting the stage for a broader debate. Environ Manag 46(1):1-6. https://doi. org/10.1007/s00267-010-9531-1

16. Haaren C (2018) Umwelträume und Entscheidungsräume: Wie können "problems of spatial fit" in der Landschaftsplanung gelöst werden? In: Hennecke S (ed) (2018) Diedrich Bruns wird gelehrt haben. Eine Festschrift, Kassel

17. Hardin G (1968) The tragedy of the commons. Science 162(3859):12431248. https://doi.org/10.1126/science.162.3859.1243

18. Newig J, Fritsch O (2009) Environmental governance. Participatory, multi-level - and effective? Environ Policy Gov 19(3):197-214. https:/doi.org/10.1002/eet.509

19. Leach WD, Pelkey NW, Sabatier PA (2002) Stakeholder partnerships as collaborative policymaking: evaluation criteria applied to watershed management in California and Washington. J Policy Anal Manag 21(4):645670. https://doi.org/10.1002/pam.10079

20. Yearley S, Cinderby S, Forrester J, Bailey P, Rosen P (2003) Participatory modelling and the local governance of the politics of UK air pollution: a three-city case study. Environ Values 12(2):247-262

21. Seng M (2019) Koalition im Land ist beim Klimaschutz völlig zerstritten. Hannoversche Allgemeine Zeitung. Article of 28 June 2019. https://www. haz.de/Nachrichten/Politik/Niedersachsen/Klimaschutzgesetz-Koalition-inNiedersachsen-beim-Klimaschutz-voellig-zerstritten. Accessed 19 July 2019.

22. Mostert E (2015) Who should do what in environmental management? Twelve principles for allocating responsibilities. Environ Sci Pol 45:123-131. https://doi.org/10.1016/j.envsci.2014.10.008

23. Niedersächsisches Ministerium für Ernährung, Landwirtschaft und Verbraucherschutz (ed.) (2017) Neubekanntmachung der Verordnung über das Landes-Raumordnungsprogramm Niedersachsen (LROP-VO). Nds. GVBI. Nr. 20/2017

24. Region Hannover (2016) Regionales Raumordnungsprogramm Region Hannover

25. BMWi Bundesministerium für Wirtschaft und Energie $(\mathrm{Hg})(2018)$ Erneuerbare Energien in Zahlen. Nationale und internationale Entwicklung im Jahr 2017. 80 S

26. EEG Erneuerbare-Energien-Gesetz (2017) Gesetz für den Ausbau erneuerbarer Energien. Zuletzt geändert durch Art. 1 G v. 17.12.2018 | 2549

27. INER - Institut für Nachhaltige Energie- und Ressourcennutzung, SUER Stiftung Umweltenergierecht (eds) (2016): Instrumente für eine verbesserte räumliche Steuerung der Stromversorgung aus erneuerbaren Energien. $323 \mathrm{~S}$

28. EEAV Erneuerbare-Energien-Ausführungsverordnung (2017) Verordnung zur Ausführung der Erneuerbare-Energien-Verordnung. Zuletzt geändert durch Art. 4 V v. 10.8.2017 | 3102

29. ROG (2017) Raumordnungsgesetz vom 22. Dezember 2008 (BGBI. I S. 2986), das zuletzt durch Artikel 2 Absatz 15 des Gesetzes vom 20. Juli 2017 (BGBI. I S. 2808) geändert worden ist

30. Germelmann C. F. (2017) Rechtliche Rahmenbedingungen der Umsetzung naturschutzkonformer Erzeugung von 100\% erneuerbarer Energien bis 2050 insbesondere durch die Raumordnung und das EEG 2016. In: Walter et al. (2018) Naturverträgliche Energieversorgung aus 100\% erneuerbaren Energien 2050. Materialband. $20 \mathrm{~S}$

31. Secretariat of the Standing Conference of Ministers responsible for Spatial Planning Federal Ministry of Transport and Digital Infrastructure (BMVI) (ed.) (2016) Concepts and Strategies for Spatial Development in Germany. Decision of the 41st Standing Conference of Ministers responsible for Spatial Planning in Berlin on 09 March 2016. Berlin. 40 S

32. Schneider D \& Boenigk N (2012) Planungsrecht \& Erneuerbare Energien. Agentur für Erneuerbare Energien e. V. (ed.). Renews Spezial Nr. 62. $33 \mathrm{~S}$

33. Schwarzenberg L, Ruß S, Sailer F (2016) Aktuelle Entwicklungen im Bereich der Windenergieerlasse der Länder. Würzburger Berichte zum Umweltenergierecht Nr. 19 vom 05.02.2016

34. Niedersächsisches Ministerium für Umwelt, Energie und Klimaschutz (2016) Planung und Genehmigung von Windenergieanlagen an Land (Windenergieerlass) Gem. RdErl. d. MU, d. ML, d. MS, d. MW u. d. MI v. 24. 2 . 2016. Nds MBI Nr 7/2016 
35. BBSR - Bundesinstitut für Bau-, Stadt- und Raumforschung (ed) (2015) Steuerung der Windenergie durch die Regionalplanung - gestern, heute, morgen. BBSR-Analysen KOMPAKT 09/2015. $16 \mathrm{~S}$

36. State Capital Hannover \& Hannover Region (eds.) (2014) 100\% for climate protection - climate-neutral region 2050. 44 S

37. Klimaschutzagentur Region Hannover (ed)(2017) Nutzung von Windenergie in der Region Hannover - Wissenswertes über Windenergie. $6 \mathrm{~S}$

38. Stadt Barsinghausen (ed) (2019) Sachlicher Teilflächennutzungsplan "Windenergie" ( $\$ 5$ Abs. 2b Bau GB). Vorentwurf zur frühzeitigen Beteiligung der Öffentlichkeit und der Behörden ( $\$ 3$ Abs. 1 und $\S 4$ Abs 1 BauGB). https://www.barsinghausen.de/regional/bauleitplanung/sachlicher-teilflaechennutzungsplan-windenergie\%2D\%2D903000377-20002. html?plantyp=f\&titel=Sachlicher+Teil-Fl\%C3\%A4chennutzungsplan+\%E2\% 80\%9EWindenergie\%E2\%80\%9C, Accessed 19 July 2019

39. Landesportal Schleswig-Holstein (2018) Landesplanung - OVG-Urteile zu Wind-Regionalplänen 2012. https://www.schleswig-holstein.de/DE/ Schwerpunkte/Windenergieflaechen/_documents/Ausnahmesteuerung.html, Accessed 15 Feb 2019

40. Klein M (2018) Mehrere Regionskommunen klagen gegen Windräder. Hannoversche Allgemeine Zeitung (HAZ). Artikel vom 6.9.2018. http://www. haz.de/Hannover/Aus-der-Stadt/Windenergie-in-der-Region-HannoverKommunen-klagen-gegen-Windraeder. Accessed 15 Feb 2019

41. Haase B (2019) Region hinkt ihren Klimazielen hinterher. Hannoversche Allgemeine Zeitung (HAZ). Artikel vom 7.2.2019. http://www.haz.de/ Hannover/Aus-der-Stadt/Region-Hannover-hinkt-hinter-Klimazielen-zurueck. Accessed 15 Feb 2019

\section{Publisher's Note}

Springer Nature remains neutral with regard to jurisdictional claims in published maps and institutional affiliations.

Ready to submit your research? Choose BMC and benefit from:

- fast, convenient online submission

- thorough peer review by experienced researchers in your field

- rapid publication on acceptance

- support for research data, including large and complex data types

- gold Open Access which fosters wider collaboration and increased citations

- maximum visibility for your research: over $100 \mathrm{M}$ website views per year

At $\mathrm{BMC}$, research is always in progress.

Learn more biomedcentral.com/submissions 